\title{
Surgical Results of Pediatric Patients with Hypothalamic Hamartoma
}

\author{
Pediatrik Hipotalamik Hamartomlu Olgularda \\ Cerrahi Sonuçlarımız
}

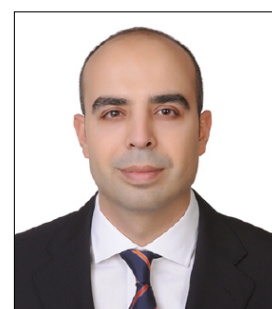

Dr. Bahattin TANRIKULU

\author{
(D) Bahattin TANRIKULU, (1) M. Memet ÖZEK
}

Department of Neurosurgery, Division of Pediatric Neurosurgery, Acıbadem University Faculty of Medicine, İstanbul, Turkey

\begin{abstract}
Summary
Objectives: Hypothalamic hamartomas $(\mathrm{HH})$ are congenital lesions present with gelastic seizures and precocious puberty. Disconnective surgery is a safe and effective treatment method in patients with $\mathrm{HH}$. In this study, we aim to share demographic information, presenting symptoms, surgical complications and surgical outcomes in pediatric patients with $\mathrm{HH}$ who were operated in our clinic.

Methods: In this retrospective study, 12 pediatric patients with $\mathrm{HH}$, who were operated in Acibadem University, School of Medicine, Department of Neurosurgery, Division of Pediatric Neurosurgery and Epilepsy Surgery Clinic between years 2007-2018 were included. All clinical materials, including patient notes, cranial magnetic resonance imaging, electroencephalogram recordings and endocrinological data of patients, were collected. Variables evaluated in the statistical analysis were age, sex, presenting symptom, radiological appearance, treatment outcome. Surgical outcome was evaluated by the Engel classification system. Statistical analysis was performed using SPSS 20.0 software.

Results: There were eight (66.7) males and four (33.3\%) females within the patient cohort. Median age at the time of diagnosis was 3.1 years (4 months-6 years). Median follow-up period was 98.3 months (24-177 months). Presenting symptoms were gelastic seizures in six (50\%) patients, precocious puberty in three $(25 \%)$ patients and both gelastic seizures and precocious puberty in three patients. All patients had disconnective surgery for HH. None of the patients had a postoperative neurological deficit. The seizure outcome in seven (77\%) of the nine patients with seizure were Engel class 1 after the surgery. Signs and symptoms of precocious puberty persist after surgery in three (50\%) of six patients who had presented with precocious puberty in the preoperative period. There was no statistically significant relationship between age, sex and type of $\mathrm{HH}(\mathrm{p}>0.05$ ). There was also no significant relationship between the type of $\mathrm{HH}$ and presenting symptom, operation route or treatment outcome $(\mathrm{p}>0.05)$.

Conclusion: Disconnective surgery is a safe and effective treatment method in pediatric patients with $\mathrm{HH}$. Since most of the patients presents with seizures and/or endocrinological problems, thorough preoperative and postoperative neurological and endocrinological follow-up is recommended.

Keywords: Disconnective surgery; gelastic seizure; Hypothalamic hamartoma; precocious puberty.
\end{abstract}

\section{Özet}

Amaç: Hipotalamik Hamartomlar (HH) genellikle jelastik nöbet ve erken ergenlik ile bulgu veren konjenital lezyonlardır. Hipotalamik hamartom hastalarında diskonnektif cerrahi güvenli bir tedavi yöntemidir. Bu çalışmadaki amacımız, kliniğimizde opere edilen pediatrik yaş grubundaki hipotalamik hamartomlu hastaların demografik verileri, başvuru şikayetleri, cerrahi komplikasyonları ve sonuçlarını paylaşmaktır.

Gereç ve Yöntem: Bu geriye dönük çalışmaya Acıbadem Üniversitesi Tıp Fakültesi Pediatrik Beyincerrahsi Bilim Dalı ve epilepsi cerrahisi kliniğinde 2007-2018 yılları arasında ameliyat edilen 12 pediatrik HH hastası dahil edilmiştir. Olguların dosyaları, beyin manyetik rezonans görüntülemeleri, elektroensefalogram kayıtları ve endokrinolojik tetkik ve konsültasyonları değerlendirilmiştir. Nöbet şikayeti olan hastalarda cerrahi nöbet başarısı Engel sınıflandırma sistemi ile değerlendirilmiştir. İstatistiksel analizler için SPSS 20.0 programı kullanılmıştır.

Bulgular: Çalışmada sekiz (66.7) erkek ve dört (33.3\%) kadın hasta bulunmaktadır. Tanı anındaki ortanca yaş 3.1 yıldır (4 ay-6 yıl). Ortanca takip süresi 98.3 aydır (24-177 ay). Başvuru anında altı (50\%) hastada jelastik nöbet, üç (25\%) hastada erken ergenlik bulguları ve üç (25\%) hastada hem jelastik nöbet hem de erken ergenlik bulguları mevcuttu. Tüm hastalara diskonnektif cerrahi uygulanmıştır. Nöbet şikayeti olan dokuz hastanın yedisi (77\%) ameliyat sonrasında nöbet açısından Engel sınıf 1'dir. Erken ergenlik bulguları olan altı hastanın üç (50\%) tanesinde bu bulgular ameliyat sonrası devam etmiştir. Hastaların yaşı cinsiyeti ile HH tipi arasında istatistiksel ilişki saptanmamıştır ( $p>0.05$ ). Ayrıca HH tipi ile başvuru şikayeti, operasyon türü ve operasyon başarısı arasında ilişki saptanmamıştır ( $\mathrm{p}>0.05)$.

Sonuç: Pediatrik HH olgularında diskonnektif cerrahi güvenli ve etkili bir tedavi metodudur. Hastaların genellikle nöbet ve/veya erken ergenlik bulguları ile başvurduğu için ameliyat öncesi ve sonrası tüm hastaların detaylı bir çocuk nörolojisi ve çocuk endokrinolojisi muayenesinde geçmesi gerekmektedir.

Anahtar sözcükler: Diskonnektif cerrahi; erken ergenlik; hipotalamik hamartom; jelastik nöbet.

(c) 2020 Türk Epilepsi ile Savaş Derneği

(C) 2020 Turkish Epilepsy Society
Submitted (Geliş): 05.08.2019

Accepted (Kabul) : 13.01.2020

Correspondence (illetişim): Bahattin TANRIKULU, M.D. e-mail (e-posta): bahattintanrikulu@gmail.com 


\section{Introduction}

Hypothalamic hamartomas $(\mathrm{HH})$ are rare congenital, non-neoplastic lesions, organized as clusters of both neuronal and glial cells within walls or floor of the third ventricle.

${ }^{[1]}$ They generally present with gelastic seizures (GS) and/or precocious puberty (PP). ${ }^{[2,3]}$ Less frequently, they may also present with cognitive dysfunction and behavioral disturbances. ${ }^{[4,5]}$ Epilepsy in $\mathrm{HH}$ generally stars as GS in early years of life and later it may evolve into other types of seizures, which may result in epileptic encephalopathy. ${ }^{[1,2]}$ Epilepsy that arises from $\mathrm{HH}$ is generally refractory to antiepileptic drugs (AED). Surgery, stereotactic radiosurgery, interstitial brachytherapy, radiofrequency thermocoagulation and laser interstitial thermal therapy are treatment options in patients with symptomatic HHs, especially with refractory epilepsy. In this study, we aimed to report our clinical experience with 12 pediatric hypothalamic patients all of whom were treated with disconnective $\mathrm{HH}$ surgery.

\section{Materials and Methods}

In this study, we reviewed the clinical data of 12 pediatric patients with a diagnosis of hypothalamic hamartomas who were operated at Acibadem University, School of Medicine, Department of Neurosurgery, Division of Pediatric Neurosurgery and Epilepsy Surgery clinic between 20072018. This retrospective study was approved by the medical ethical committee at Acıbadem University School of Medicine, Istanbul, Turkey.

\section{Pre-surgical patient evaluation}

All the patients had 3 Tesla magnetic resonance imaging (MRI), including sagittal, axial section turbo spin echo (TSE) T2 weighted imaging, coronal section fat-sat TSE T2 weighted diffusion, sagittal section 3-dimensional (3D) Turbo-FLAIR T2 with reconstructions, sagittal section 3D turbo flash T1 with reconstructions, axial section 3D susceptibility-weighted imaging and diffusion tensor imaging tractography protocol as described in our previous publication. ${ }^{[6]}$ Delalande radiological classification system was employed. ${ }^{[1]}$ All patients presented with seizures had at least 48-hour, 21 channel video electroencephalogram (EEG) monitoring with at least three ictal recordings. They all had preoperative blood tests for hemogram, electrolyte, bleeding parameters and serology. All patients presented either with seizures and/or precocious puberty had through pediatric endocrinological evaluation and they were evaluated by a clinical pediatric psychologist as a member of the pediatric neurosurgery and epilepsy surgery team.

\section{Surgery}

Patients were operated through one of the interhemispheric, pterional, subtemporal or subfrontal approaches. All patients had disconnective surgery, which aimed just to sever the connection of $\mathrm{HH}$ with the hypothalamus without removing the whole $\mathrm{HH}$ tissue. Only one patient who needed a second surgery for seizure control had resective surgery for $\mathrm{HH}$ during the second operation. All operations were performed by the senior author (MMÖ).

\section{Postoperative follow-up}

Each patient was observed in the pediatric neurosurgical intensive care unit for $\mathbf{2 4}$ hours and four days in the patient ward. All patients who presented with epilepsy continued their antiepileptic drugs with the same doses after surgery. They were followed by a pediatric endocrinologist concerning hormonal abnormalities, especially diabetes insipidus postoperatively. During routine follow-up, all patients were evaluated by a pediatric neurosurgeon, and patients who presented with seizure also evaluated by pediatric epileptologist every three months during the first postoperative year, every six months during the second postoperative year and yearly thereafter. All patients presented with seizure had control EEG recordings starting from three months after the surgery. Antiepileptic dose adjustments were performed according to EEG results by the pediatric epileptologist.

\section{Evaluation of outcome and statistical analysis}

Statistical analysis was performed with SPSS 20. Variables evaluated in the statistical analysis were age, sex, presenting symptom, radiological appearance, treatment outcome. Seizure outcome was evaluated according to Engel's classification. ${ }^{[7]}$

\section{Results}

Clinical data of the patients are summarized in Table 1. Total number of patients in the study group was 12 . There were eight (66.7\%) males and four (33.3\%) females. Median age at the time of diagnosis was 3.1 years ( 4 months- 6 years). Median follow-up period was 98.3 months (24-177 months). Presenting symptoms were gelastic seizures in six (50\%) patients (case 1, 2, 8, 9, 10 and 11), precocious puberty in three (25\%) patients (case 4, 5 and 7) and both gelastic seizures 


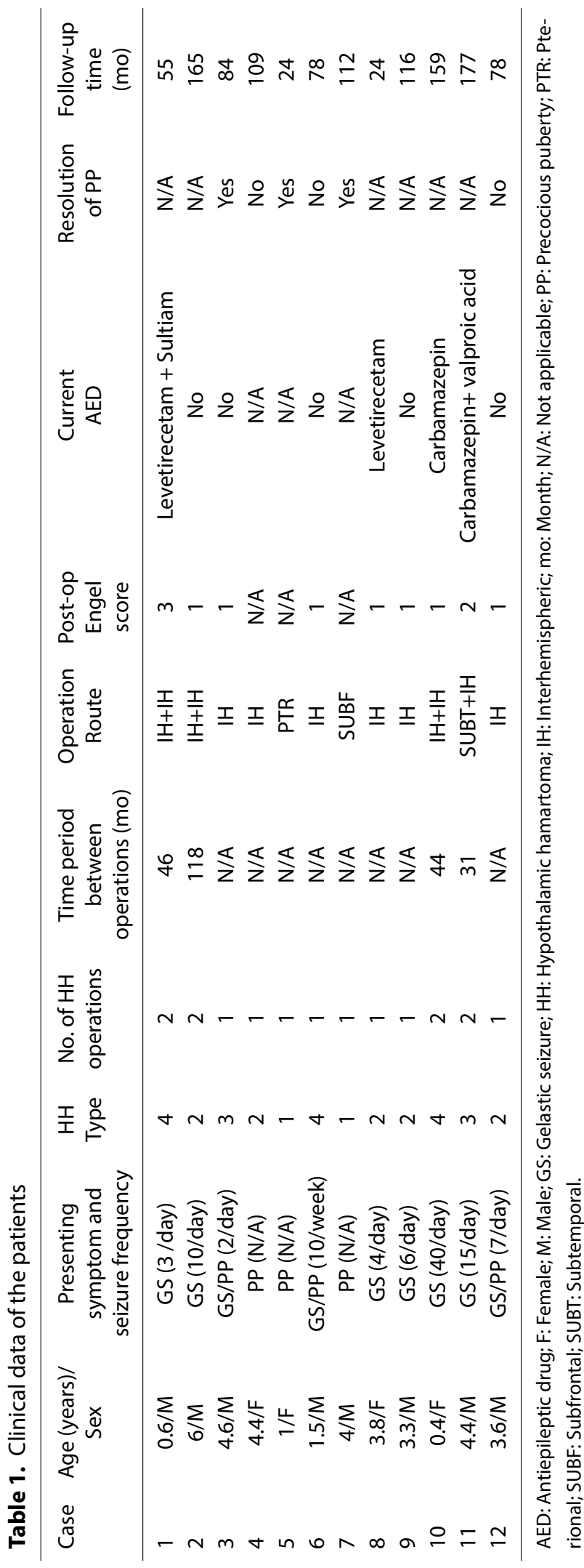

and precocious puberty in three (25\%) patients (case 3, 6 and 12). Radiologically all lesions were isointense to surrounding brain parenchyma in T1 and T2 weighted MR images without contrast enhancement. The radiological diagnosis of patients was consistent with type $1 \mathrm{HH}$ in two (16.7) patients, type $2 \mathrm{HH}$ in five (41.7) patients, type $3 \mathrm{HH}$ in two (16.7) patients and type $4 \mathrm{HH}$ in three (25\%) patients. All patients were operated within three months after diagnosis. Nine patients $(75 \%)$ were operated through interhemispheric approach, one patient (8.3\%) was operated through subfrontal approach, one patient (8.3\%) was operated through the pterional approach and one patient (8.3\%) was operated through the subtemporal approach (Fig 1-4). Four (33.3\%) patients were operated twice. One of these patients (case 2 ) had been operated and also had postoperative stereotactic radiosurgery (SRS) treatment in another institution previously. Since his symptoms persisted, he had his second operation in our clinic. Case 11 was operated through the subtemporal approach for $\mathrm{HH}$ disconnection during the first operation. Since his seizures had persisted, he had the second operation through interhemispheric approach for total resection of $\mathrm{HH}$. There was no postoperative neurological deficit in any patient. Post-operative seizure outcomes of nine patients who had gelastic seizures were Engel class 1 in seven (77\%) patients, Engel class 2 in one patient and Engel class 3 in one patient. Three patients, the one with type $4 \mathrm{HH}$ (case 1) and two other patients with type $2 \mathrm{HHs}$ (case 9 and 12), had early postoperative diabetes insipidus, which mandated nasal antidiuretic hormone usage. Diabetes insipidus was resolved completely in all patients within two weeks after surgery. Cases 3-4-5-6-7-12 presented with precocious puberty (PP). Precocious puberty was completely resolved in cases 3,5 and 7 within three months after surgery, but it persists in cases 4, 6 and 12 in whom LHRH releasing hormone treatment were indicated.

There was no statistically significant relationship between age, sex and type of $\mathrm{HH}(\mathrm{p}>0.05)$. There was also no significant relationship between type of $\mathrm{HH}$ and presenting symptom, operation route or treatment outcome ( $p>0.05$ ).

\section{Discussion}

Hypothalamic hamartomas are congenital non-progressive malformations of anterior hypothalamus..$^{[8]}$ Although gelastic seizures are the most common presenting symp- 

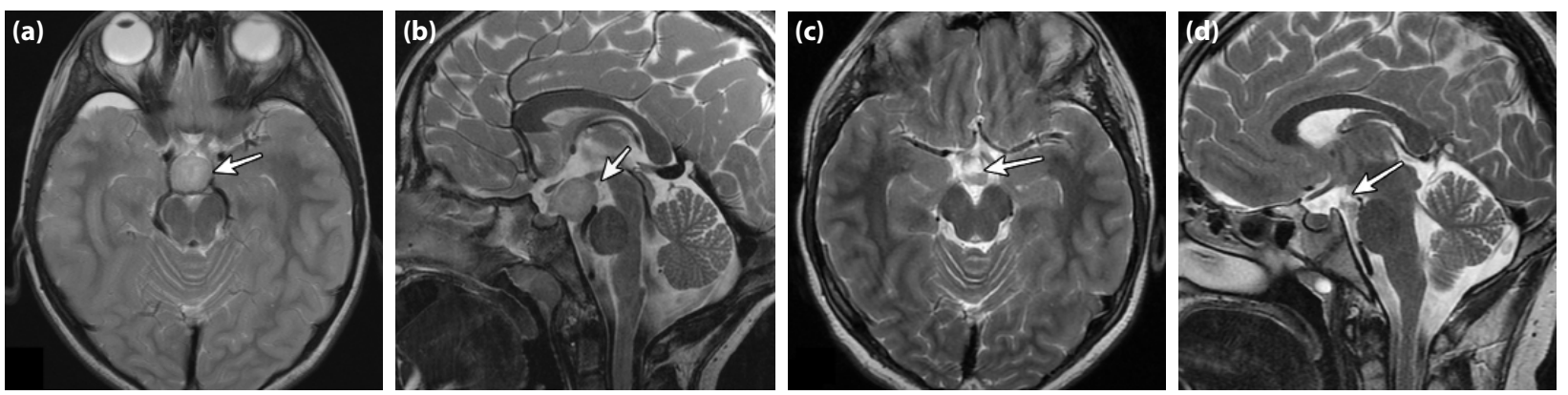

Fig. 1. (a) Axial section $T 2$ weighted MRI of a patient with type $1 \mathrm{HH}$ (arrow). (b) Sagittal section T2 weighted MRI of the same patient (arrow). (c) Axial section T2 weighted MRI of the patient after disconnection surgery through pterional route. Arrow designates disconnection plane. (d) Sagittal section T2 weighted MRI of the same patient after disconnection surgery. Arrow designates the disconnection plane.
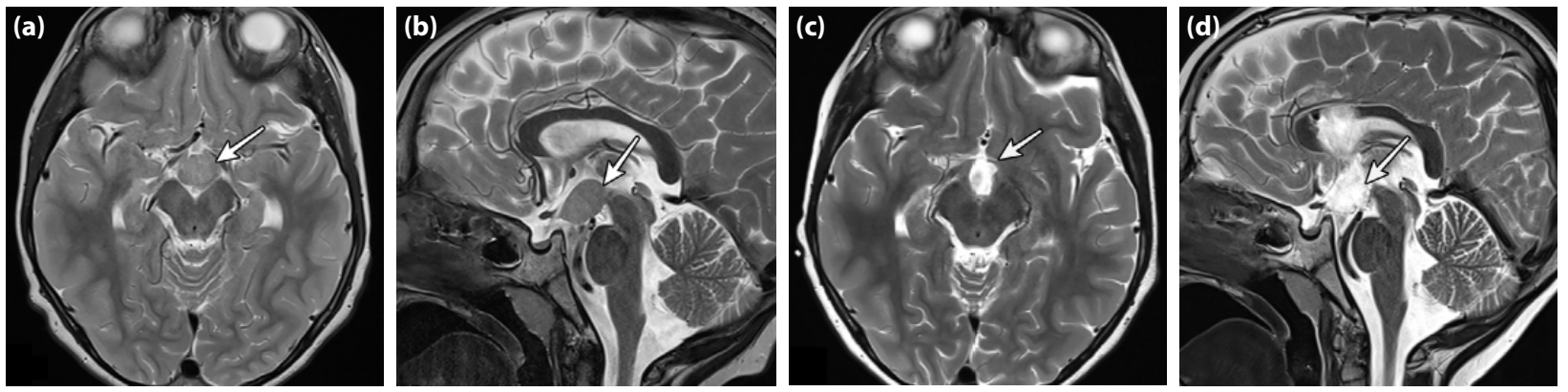

Fig. 2. (a) Axial section $T 2$ weighted MRI of a patient with type $2 \mathrm{HH}$ (arrow). (b) Sagittal section $T 2$ weighted MRI of the same patient (arrow). (c) Axial section T2 weighted MRI of the patient after disconnection surgery through the interhemispheric route. Arrow designates disconnection plane. (d) Sagittal section T2 weighted MRI of the same patient after disconnection surgery. Arrow designates the disconnection plane.
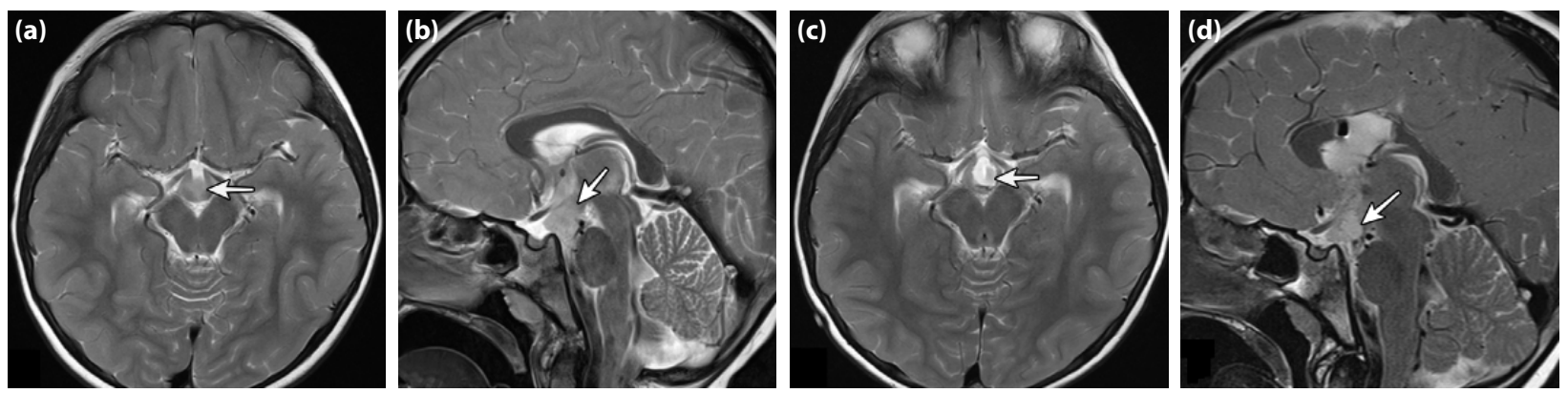

Fig. 3. (a) Axial section $T 2$ weighted MRI of a patient with type $3 \mathrm{HH}$ (arrow). (b) Sagittal section T2 weighted MRI of the same patient (arrow). (c) Axial section T2 weighted MRI of the patient after disconnection surgery through the interhemispheric route. Arrow designates disconnection plane. (d) Sagittal section T2 weighted MRI of the same patient after disconnection surgery. Arrow designates the disconnection plane.

tom, they may also present with precocious puberty, cognitive problems, such as speech retardation, learning difficulties and behavioral changes, such as difficulties in anger control, oppositional-defiant disorder. ${ }^{[4,5]}$ Gelastic seizures are characteristic seizure types associated with $\mathrm{HH} .{ }^{[9]}$ They consist of short, repeated behaviors, which are like laughter, generally lasts $10-20$ s. $^{[10]}$ More than $80 \%$ of patients with gelastic seizures secondary to HH may also develop other types of seizures, which are very resistant to antiepileptic drug treatment and mandate $\mathrm{HH}$ disconnection surgery. ${ }^{[11,12]}$

Delalande et al. ${ }^{[1]}$ classified $\mathrm{HH}$ into four main categories according to their insertion planes to the hypothalamus. They described type 1 as the one which has a horizontal im- 

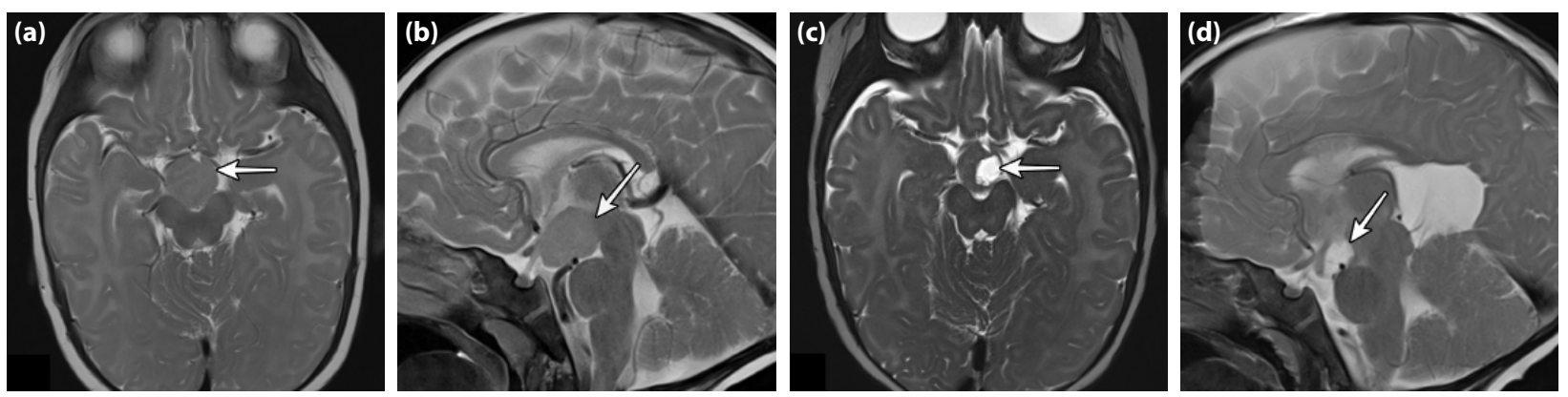

Fig. 4. (a) Axial section $T 2$ weighted MRI of a patient with type $4 \mathrm{HH}$ (arrow). (b) Sagittal section $\mathrm{T} 2$ weighted MRI of the same patient (arrow). (c) Axial section T2 weighted MRI of the patient after disconnection surgery through the interhemispheric route. Arrow designates disconnection plane. (d) Sagittal section T2 weighted MRI of the same patient after disconnection surgery. Arrow designates the disconnection plane.

plantation plane to the hypothalamus at the level of tuber cinereum. Type 2 was described as the one with a vertical insertion plane to the hypothalamus and located within the third ventricle. Type 3 was described as the combination with type 1 and 2 . Type 4 describes the giant hamartomas. They recommended a pterional route for type $1 \mathrm{HH}$, endoscopic or interhemispheric microneurosurgical disconnection for type $2 \mathrm{HH}$, and staged surgery as a combination of pterional and interhemispheric approaches for type 3. They did not recommend any specific type of surgery for type 4 $\mathrm{HH} \cdot{ }^{[1]}$ We had 2 type $1 \mathrm{HH}(16.7 \%), 5$ type $2 \mathrm{HH}(41.6 \%), 2$ type $3 \mathrm{HH}(16.7 \%)$ and 3 type $4 \mathrm{HH}(25 \%)$ in our patient cohort. One of the type $1 \mathrm{HH}$ lesions was operated through pterional approach; the other type $1 \mathrm{HH}$ patient hamartoma was operated through subfrontal approach. All of the remaining 10 patients were operated through the interhemispheric approach.

Valdueza et al. ${ }^{[13]}$ classified the $\mathrm{HH}$ based on the localization. They describe the type $1 \mathrm{HH}$ as small lesions with tiny attachments to the tuber cinereum, whereas type 2 lesions as relatively large $3^{\text {rd }}$ ventricular lesions, which displaces the hypothalamus. ${ }^{[13]}$ They also proposed that type 1 lesions are more commonly associated with PP, whereas type 2 lesions are commonly associated with gelastic and other seizure types. ${ }^{[13]}$ Arita et al. ${ }^{[4]}$ also classified HHs into two main groups as parahypothalamic $\mathrm{HH}$ and intrahypothalamic type. The parahypothalamic type is very similar to type 1 $\mathrm{HH}$ and intrahypothalamic one is very similar to type $2 \mathrm{HH}$ described by Valdueza et al. ${ }^{[13]}$

Hypothalamic hamartomas located within the hypothalamus and $3^{\text {rd }}$ ventricle are more commonly associated with seizures, whereas $\mathrm{HHs}$ located at the level of tubercinereum are more commonly presented with precocious puberty. ${ }^{[14]}$ The gelastic seizures may be triggered by epileptogenic activity propagated in the $\mathrm{HH}$ through neuronal connections, which are present only in $\mathrm{HHs}$ or also may be triggered by direct hypothalamic compression by the $\mathrm{HHs}$ within third ventricle. ${ }^{[14]}$ Precocious puberty may be caused by excessive GnRH secretion from the lesion or epileptic discharges stimulates neurons to secrete an excess amount of $\mathrm{GnRH}$.

Since PP mainly encountered in parahypothalamic HHs, they can be easily accessed and safely disconnected through surgery to treat PP. ${ }^{[15-17]}$ There was 2 Delalande type $1 \mathrm{HH}$ (case 5 and 7) in our patient cohort, which can also be grouped as parahypothalamic hamartomas, and both of which were presented with PP. Precocious puberty was totally disappeared in both patients after $\mathrm{HH}$ surgery. There were also one type $2 \mathrm{HH}$ patient (case 4) presented with PP and one type $2 \mathrm{HH}$ patient (case 12) presented with both GS and PP. Precocious puberty did not resolved in both patients. There was one type $3 \mathrm{HH}$ patient (case 3) presented with both GS and PP in whom PP was completely resolved after $\mathrm{HH}$ disconnection surgery. There was also one type $4 \mathrm{HH}$ patient (case 6) presented with both GS and PP in whom PP did not resolve after $\mathrm{HH}$ disconnection surgery. Although symptoms of patients according to tol localizations were similar in our cohort, there was no statistically significant relationship between the type of $\mathrm{HH}$ and the presenting symptom of patients. This may be because of the small number of the patient group.

There are several types of surgical routes described to treat $\mathrm{HH}$ patients. In all of them, the main aim was the total removal of the $\mathrm{HH}$ since it is thought to be the reason for GS and PP. ${ }^{[18]}$ Delalande et al. ${ }^{[1]}$ proposed that complete remov- 
al of the $\mathrm{HH}$ can be replaced by disconnection of $\mathrm{HH}$ from the hypothalamus either with craniotomy or endoscopic surgery. All of the cases included in our patient cohort had a disconnective type of surgery since the risk postoperative neurological deficit is lower than the resective surgery. ${ }^{[1]}$ Overall success rates of all kinds of $\mathrm{HH}$ surgery concerning seizure reduction differ between $43 \%-68 \%{ }^{[18,19]}$ In our patient cohort, 88.8\% (8 in 9) of patients showed more than 90\% seizure reduction (Engel class 1-2), and $77.7 \%$ (7 in 9) of patients with seizure were totally cured.

Stereotactic radiosurgery is also an alternative to $\mathrm{HH}$ surgery for patients who present with epilepsy. Régis et al. ${ }^{[20]}$ reported their series of eight patients with $\mathrm{HH}$ who were treated with SRS. They reported a total cure in four patients, and moderate improvement in the remaining four patients in terms of epilepsy with a mean latency period of nine months. Recently, Régis et al. ${ }^{[21]}$ published their experience with SRS in $57 \mathrm{HH}$ patients and they reported more than $50 \%$ seizure reduction rate. Overall seizure reduction rates of SRS in $\mathrm{HH}$ patients are reported to range between $27 \%$ $66 \%$ in the literature. ${ }^{[22-25]}$ However, the success rate of SRS in patients with type 4 giant $\mathrm{HHs}$ is still low. ${ }^{[21]}$

There was only one patient (case 2) in our cohort with type $4 \mathrm{HH}$, who had post-operative SRS treatment after a failed surgery performed in another institution. He did not benefit from both procedures and was re-operated in our clinic. Now, he is still free of seizures during 55 months of follow-up.

Radiofrequency thermocoagulation, laser interstitial thermal therapy and interstitial brachytherapy are other less commonly used treatment options in $\mathrm{HH}$ patients with epilepsy. ${ }^{[1,26]}$

Although there have been different kinds of treatment options for $\mathrm{HHs}$, we recommend disconnective surgery as the first treatment of choice. If it fails besides successful disconnection surgery, SRS treatment may be employed.

\section{Conclusion}

Hypothalamic hamartomas are rare congenital lesions generally present with refractory epilepsy and/or precocious puberty. Disconnective surgery is the first-line treatment option with very low post-operative complications in symptomatic HH patients. Surgical approach depends on the type of HH. Detailed post-operative neurological and endocrinological follow-up is recommended. Stereotactic radiosurgery may be used as an adjunct treatment in patients with unsatisfactory surgical outcome.

\section{Ethics Committee Approval}

Ethics committee approved.

\section{Peer-review}

Externally peer-reviewed.

\section{Conflict of interest}

The authors declare that they have no conflict of interest.

\section{Authorship Contributions}

Concept: B.T.; Design: B.T.; Supervision: M.M.Ö.; Materials: B.T.; Data collection \&/or processing: B.T., M.M.Ö.; Analysis and/or interpretation: B.T., M.M.Ö.; Literature search: B.T.; Writing: B.T.; Critical review: M.M.Ö.

\section{References}

1. Delalande O, Fohlen M. Disconnecting surgical treatment of hypothalamic hamartoma in children and adults with refractory epilepsy and proposal of a new classification. Neurol Med Chir (Tokyo) 2003;43(2):61-8. [CrossRef]

2. Berkovic SF, Andermann F, Melanson D, Ethier RE, Feindel W Gloor P. Hypothalamic hamartomas and ictal laughter: evolution of a characteristic epileptic syndrome and diagnostic value of magnetic resonance imaging. Ann Neurol 1988;23(5):42939. [CrossRef]

3. Comite F, Pescovitz OH, Rieth KG, Dwyer AJ, Hench K, McNemar $A$, et al. Luteinizing hormone-releasing hormone analog treatment of boys with hypothalamic hamartoma and true precocious puberty. J Clin Endocrinol Metab 1984;59(5):888-92.

4. Arita K, Ikawa F, Kurisu K, Sumida M, Harada K, Uozumi T, Monden S, Yoshida J, Nishi Y. The relationship between magnetic resonance imaging findings and clinical manifestations of hypothalamic hamartoma. J Neurosurg 1999;91(2):212-20.

5. Nguyen D, Singh S, Zaatreh M, Novotny E, Levy S, Testa F, et al. Hypothalamic hamartomas: seven cases and review of the literature. Epilepsy Behav 2003;4(3):246-58. [CrossRef]

6. Tanrıkulu, B., U. Işık, and M. Özek, M., Epilepsy Surgery in Pediatric Patients: A Single-Center Experience. Epilepsi, 2019;1:27-34.

7. Engel JJ, Rasmussen TB, Ojemann LM. Outcome with respect to epileptic seizures, in Surgical treatment of th epilepsies. New York: Raven Press; 1993 p. 609-22.

8. Kerrigan JF, Parsons A, Tsang C, Simeone K, Coons S, Wu J. Hypothalamic hamartoma: Neuropathology and epileptogenesis. Epilepsia 2017;58 Suppl 2:22-31. [CrossRef]

9. Cascino GD, Andermann F, Berkovic SF, Kuzniecky Rl, Sharbrough FW, Keene DL, et al. Gelastic seizures and hypothalamic hamartomas: evaluation of patients undergoing chronic intracranial EEG monitoring and outcome of surgical treatment. 
Neurology 1993;43(4):747-50. [CrossRef]

10. Munari C, Kahane P, Francione S, Hoffmann D, Tassi L, Cusmai $R$, et al. Role of the hypothalamic hamartoma in the genesis of gelastic fits (a video-stereo-EEG study). Electroencephalogr Clin Neurophysiol 1995;95(3):154-60. [CrossRef]

11. Freeman JL, Harvey AS, Rosenfeld JV, Wrennall JA, Bailey CA, Berkovic SF. Generalized epilepsy in hypothalamic hamartoma: evolution and postoperative resolution. Neurology 2003;60(5):762-7. [CrossRef]

12. Helen Cross J, Spoudeas H. Medical management and antiepileptic drugs in hypothalamic hamartoma. Epilepsia 2017;58 Suppl 2:16-21. [CrossRef]

13. Valdueza JM, Cristante L, Dammann O, Bentele K, Vortmeyer A, Saeger $W$, et al. Hypothalamic hamartomas: with special reference to gelastic epilepsy and surgery. Neurosurgery 1994;34(6):949-58. [CrossRef]

14. Chan YM, Fenoglio-Simeone KA, Paraschos S, Muhammad L, Troester MM, Ng YT, et al. Central precocious puberty due to hypothalamic hamartomas correlates with anatomic features but not with expression of GnRH, TGFalpha, or KISS1. Horm Res Paediatr 2010;73(5):312-9. [CrossRef]

15. Price RA, Lee PA, Albright AL, Ronnekleiv OK, Gutai JP. Treatment of sexual precocity by removal of a luteinizing hormone-releasing hormone secreting hamartoma. JAMA 1984;251(17):22479. [CrossRef]

16. Sato M, Ushio Y, Arita N, Mogami H. Hypothalamic hamartoma: report of two cases. Neurosurgery 1985;16(2):198-206. [CrossRef]

17. Romner B, Trumpy JH, Marhaug G, Isaksson HJ, Anke IM. Hypothalamic hamartoma causing precocious puberty treated by surgery: case report. Surg Neurol 1994;41(4):306-9. [CrossRef]

18. Palmini A, Chandler C, Andermann F, Costa Da Costa J, Paglioli-Neto E, Polkey C, et al. Resection of the lesion in patients with hypothalamic hamartomas and catastrophic epilepsy.
Neurology 2002;58(9):1338-47. [CrossRef]

19. Miranda P, Esparza J, Cabrera A, Hinojosa J. Giant hypothalamic hamartoma operated through subfrontal approach with orbitary rim osteotomy. Pediatr Neurosurg 2006;42(4):254-7.

20. Régis J, Bartolomei F, de Toffol B, Genton P, Kobayashi T, Mori Y, et al. Gamma knife surgery for epilepsy related to hypothalamic hamartomas. Neurosurgery 2000;47(6):1343-51. [CrossRef]

21. Régis J, Lagmari M, Carron R, Hayashi M, McGonigal A, Daquin $G$, et al. Safety and efficacy of Gamma Knife radiosurgery in hypothalamic hamartomas with severe epilepsies: A prospective trial in 48 patients and review of the literature. Epilepsia 2017;58 Suppl 2:60-71. [CrossRef]

22. Barajas MA, Ramírez-Guzman MG, Rodríguez-Vázquez C, Toledo-Buenrostro V, Cuevas-Solórzano A, Rodríguez-Hernández G. Gamma knife surgery for hypothalamic hamartomas accompanied by medically intractable epilepsy and precocious puberty: experience in Mexico. J Neurosurg 2005;102 Suppl:53-5.

23. Mathieu D, Kondziolka D, Niranjan A, Flickinger J, Lunsford LD. Gamma knife radiosurgery for refractory epilepsy caused by hypothalamic hamartomas. Stereotact Funct Neurosurg 2006;84(2-3):82-7. [CrossRef]

24. Régis J, Scavarda D, Tamura M, Nagayi M, Villeneuve N, Bartolomei $F$, et al. Epilepsy related to hypothalamic hamartomas: surgical management with special reference to gamma knife surgery. Childs Nerv Syst 2006;22(8):881-95. [CrossRef]

25. Unger F, Schröttner O, Feichtinger M, Bone G, Haselsberger K, Sutter B. Stereotactic radiosurgery for hypothalamic hamartomas. Acta Neurochir Suppl 2002;84:57-63. [CrossRef]

26. Tandon V, Chandra PS, Doddamani RS, Subianto H, Bajaj J, Garg $A$, et al. Stereotactic Radiofrequency Thermocoagulation of Hypothalamic Hamartoma Using Robotic Guidance (ROSA) Coregistered with O-arm Guidance-Preliminary Technical Note. World Neurosurg 2018;112:267-74. [CrossRef] 